\title{
Removal of triazine herbicides from freshwater systems using photosynthetic microorganisms
}

\author{
O. González-Barreiro, C. Rioboo, C. Herrero, A. Cid, ${ }^{1}$
}

Environmental Pollution, Volume 144, Issue 1, November 2006, Pages 266-271 Soil and Sediment Remediation (SSR) — Soil and Sediment Remediation (SSR)

Received 26 October 2004, Accepted 9 December 2005, Available online 20 February 2006

DOI: 10.1016/j.envpol.2005.12.014

\begin{abstract}
The uptake of the triazine herbicides, atrazine and terbutryn, was determined for two freshwater photosynthetic microorganisms, the green microalga Chlorella vulgaris and the cyanobacterium Synechococcus elongatus. An extremely rapid uptake of both pesticides was recorded, although uptake rate was lower for the cyanobacterium, mainly for atrazine. Other parameters related to the herbicide bioconcentration capacity of these microorganisms were also studied. Growth rate, biomass, and cell viability in cultures containing herbicide were clearly affected by herbicide uptake. Herbicide toxicity and microalgae sensitivity were used to determine the effectiveness of the bioconcentration process and the stability of herbicide removal. $C$. vulgaris showed higher bioconcentration capability for these two triazine herbicides than S. elongatus, especially with regard to terbutryn. This study supports the usefulness of such microorganisms, as a bioremediation technique in freshwater systems polluted with triazine herbicides.
\end{abstract}

\section{Keywords}

Bioaccumulation; Terbutryn; Atrazine; Microalga; Cyanobacterium

\section{Introduction}

Triazines are widely used herbicides that are highly toxic and frequently appear in natural watercourses, atrazine being one of the most frequently detected pesticides in aquatic systems (Graymore et al., 2001 and Rebich et al., 2004). Atrazine (6-chloro- $N^{k}$-ethyl- $N^{k}$-isopropyl-1,3,5triazine-2,4-diamine) and terbutryn ( $N$-tert-butyl- ${ }^{4}$-ethyl-6-methyl-thio-1,3,5-triazine-2,4diamine) are pre- or post-emergence systemic herbicides. They are used to control most grasses and many annual broad-leaved weeds in winter cereals, potatoes, legumes,

\footnotetext{
${ }^{1}$ Laboratorio de Microbiología, Facultad de Ciencias, Universidad de A Coruña, Campus da Zapateira s/n. 15071 A Coruña, Spain
} 
sunflowers, maize, sugar cane and citrus fruit. Furthermore, terbutryn is used as an aquatic herbicide for controlling submerged and free-floating weeds and algae in watercourses ( Tomlin, 2003). Different studies have demonstrated that freshwater organisms, particularly freshwater microalgae, are most affected by these pollutants, more than marine organisms ( Solomon, 1996).

These herbicides affect the main energy production process in green cells, the photosynthesis (Védrine et al., 2003). Some studies have indicated that different algal species have different sensitivity to triazine herbicides, and responses vary widely depending on the species tested and the concentrations used (Blank et al., 1984 and Ma and Chen, 2005). Differences in the uptake of this type of herbicides by microalgal cells result from a complex interaction between several metabolic factors (Kent and Currie, 1995 and Weiner et al., 2004).

Since, the bioconcentration of pesticides, determined by the use of organisms of different trophic levels and taxonomic groups, is an important criteria for ecological hazard assessment for aquatic environments (Manthey et al., 1993 and Singh et al., 1997); the aim of this study was to test the capability of two freshwater microorganisms, the cyanobacterium $S$. elongatus and the chlorophyte $C$. vulgaris, commonly used in toxicity tests, to remove atrazine and terbutryn from culture media.

The results obtained in this work could contribute to test the utility and effectiveness of these microalgae as a bioremediation technique for these herbicides, which could affect higher organisms on longer time scales (McCormik and Cairns, 1994).

\section{Materials and methods}

\subsection{Microalgal cultures}

Synechococcus elongatus(Cyanophyceae) (strain CCAP 1479/1A) and Chlorella vulgaris (Oocystaceae) (strain CCAP 211/11B) obtained from the Culture Collection of Algae and Protozoa (CCAP; Cumbria, UK) were grown on sterile Bristol medium ( Brown et al., 1967), which was supplemented with different atrazine and terbutryn concentrations $(0.025 \mu \mathrm{M}, 0.1 \mu$ $\mathrm{M}, 0.75 \mu \mathrm{M}$ ). Atrazine and terbutryn were Riedel de Haën Pestanal (RdH Laborchemikalien $\mathrm{GmbH} \&$ Co.; Seelze, Germany) standards for environmental analysis. Herbicide stock solutions $(500 \mu \mathrm{M})$ were prepared by dissolving herbicide in $100 \%$ methanol and filtered through $0.2 \mu \mathrm{m}$ filter membranes. Final methanol concentration never exceeded $0.05 \%(\mathrm{v} / \mathrm{v})$, and no measurable effects in the parameters assayed were observed.

All cultures were carried out in Pyrex glass bottles containing $1500 \mathrm{ml}$ of medium. Bottles were previously rinsed with pure methanol and then with distilled water. Cultures without herbicide were included as positive control, and cultures without microalgae and with herbicide were included as negative control. Initial density of the cultures were $5 \times 10^{6}$ cells ml-1 and $9 \times 10^{6}$ cells $\mathrm{ml}^{-1}$ for $S$. elongatus and $C$. vulgaris, respectively. For the assays, cells from a $3-$ day-old culture, in the logarithmic phase of growth, were used. Cultures were illuminated with 
fluorescent light ( $70 \pm 2 \mu \mathrm{mol}$ photon $\mathrm{m}^{-2} \mathrm{~s}^{-1}$, photosynthetically active radiation), bubbled with air at a rate of $10 \mathrm{I} \mathrm{min}^{-1}$, and maintained at $18 \pm 1{ }^{\circ} \mathrm{C}$, with a dark:light cycle of $12: 12 \mathrm{~h}$. All experiments were carried out in triplicate.

\subsection{Growth measurement}

Growth of microalgal cultures under different conditions was measured by counting culture aliquots in a Coulter Epics Flow Cytometer equipped with an argon-ion excitation laser $(488 \mathrm{~nm})$, and with detectors of forward and side scatter, and four fluorescence detectors corresponding to four different wavelength intervals: 488-550 nm, 550-600 nm, 600-645 nm, and $>645 \mathrm{~nm}$. To exclude non-algal particles, fluorescence of chlorophyll a were used, and red fluorescence histograms (>645 nm) were used as gate.

Growth rate (day-1) was calculated using the following formula:

$\mu=\left[\ln \left(N_{t}\right)-\ln \left(N_{0}\right)\right] / \ln 2\left(t-t_{0}\right)$

where $N_{t}$ is the cell density (cells $\mathrm{ml}^{-1}$ ) at time $t$ (in days) and $N_{0}$ is the cell density at time 0 .

Growth data were fitted by a non-linear regression with regression wizard software (Sigma-Plot 8.0, SPSS Inc.).

\subsection{Dry biomass}

Biomass dry weight was determined according to Utting (1985). Culture aliquots (10 $\mathrm{ml})$ were filtered through previously dried and weighed Whatman GF/C filters. Thereafter, the filters were dried in an oven at $80^{\circ} \mathrm{C}$ for $72 \mathrm{~h}$. Values shown are the mean of three replicates.

\subsection{Cell viability}

Fluorescence of cells stained with propidium iodide (PI; Sigma Chemical Co.) was measured to study cell viability. Propidium iodide is unable to pass through intact cell membranes; however when a cell dies the integrity of the cell membrane fails, and PI is able to enter and stain nucleic acids, producing red fluorescence when excited with blue light(Cid et al., 1996). Red fluorescence was recorded between 600 and $645 \mathrm{~nm}$. Hence, PI can be used to discriminate between live non-fluorescent cells and non-viable fluorescent cells. Aliquots containing $0.5 \times 10^{6}$ cells ml-1 for the cyanobacterium and $1 \times 10^{6}$ cells $\mathrm{ml}^{-1}$ for the chlorophyte were treated with $\mathrm{Pl}$ to a final concentration of $3 \mu \mathrm{g} \mathrm{ml}-1$ for $15 \mathrm{~min}$.

\subsection{Determination of herbicide concentrations in cultures}

Herbicide concentration in cultures was determined in supernatants resulting from centrifugation of $200 \mathrm{ml}$ aliquots at $3000 \times \mathrm{g}$ for $15 \mathrm{~min}$ at $4{ }^{\circ} \mathrm{C}$. These supernatants were filtered through two superimposed $0.2 \mu \mathrm{m}$ MF-Millipore filters.

Atrazine and terbutryn were extracted by liquid-solid extraction and further determined by gas chromatography-mass spectrometry (GC-MS). Extractions were carried out in C18 cartridges (Waters; Sep-PakRPlus) prepared by adding $5 \mathrm{ml}$ of acetonitrile and $5 \mathrm{ml}$ Milli-Q water 
successively. Each sample $(200 \mathrm{ml})$ was passed through the cartridge at an approximate speed of $10 \mathrm{ml} \mathrm{min-1}$. Herbicides were eluted from the cartridges with $7.5 \mathrm{ml}$ of ethyl acetate and acetonitrile (1:3). Then solutions were evaporated and resuspended in $1 \mathrm{ml}$ of pure methanol.

Chromatographic separation was carried out with a J\&W DB-XLB column $(60 \mathrm{~m} \times 0.25 \mathrm{~mm} \times 0.25 \mu \mathrm{m})$. The separation procedure includes an increase of the temperature from 70 to $125^{\circ} \mathrm{C}$ at a rate of $30^{\circ} \mathrm{C} \mathrm{min-1}$, and then to $220^{\circ} \mathrm{C}$ at the same rate. This temperature was held during $10 \mathrm{~min}$. Helium was used as a carrier gas. PTV injector was run in solvent split mode using this program: initial temperature, $80^{\circ} \mathrm{C}$; split flow, $20 \mathrm{ml} \mathrm{min}^{-1}$; injection time, $0.5 \mathrm{~min}$; splitless time, $2.5 \mathrm{~min}$; transfer rate, $3.3^{\circ} \mathrm{C} \mathrm{min}{ }^{-1}$ and final temperature, $300^{\circ} \mathrm{C}$ held $10 \mathrm{~min}$. Injection volume was $2 \mu \mathrm{l}$.

Mass spectrometry was used for detection and quantification of both triazine herbicides. An ion trap mass spectrometer working in $70 \mathrm{eV}$ electron impact and ion selected monitoring (SIM) was used. For terbutryn, 185 and 226 amu ions were recorded between 25 and 31 min of the chromatogram. The ions selected for the analysis of atrazine were 200 and 215 amu that were recorded between 9 and 25 min of the run. Ion source and transfer line temperatures were set at $250^{\circ} \mathrm{C}$ and $290^{\circ} \mathrm{C}$, respectively.

Using this analytical method, the recovery rates of atrazine and terbutryn were $96 \%$ and $98 \%$, respectively.

\subsection{Determination of herbicides in microalgal biomass}

A $200 \mathrm{ml}$ aliquot of each culture was centrifuged at $3000 \times g$ for $15 \mathrm{~min}$ at $4{ }^{\circ} \mathrm{C}$. The pellet was resuspended in $20 \mathrm{ml}$ of fresh Bristol medium and shaken vigorously. The cell suspension was centrifuged again, and the pellet resuspended in $5 \mathrm{ml}$ of pure methanol, which was kept in darkness for $48 \mathrm{~h}$, and then the cells were disrupted by ultrasounds with two pulses of $30 \mathrm{~s}$. Finally, this methanol suspension was centrifuged again with the aim to obtain a clean supernatant, free of cell debris, which will be used for herbicide analysis as described above.

\subsection{Data analysis}

Since three microalgal cultures were carried out for each herbicide concentration analysed, and all experiments were conducted three times, data were statistically analysed by a one-way analysis of variance (ANOVA) and, when differences observed were significant, means were compared by the multiple range Duncan test. Significant differences at a level of significance of $0.05(P<0.05)$ are represented by an asterisks $\left(^{*}\right)$. Data are given as means values \pm standard errors of the means.

\section{Results}

\subsection{Growth}


Addition of atrazine to the culture medium affected the growth of both species, resulted in a significant (ANOVA test, $P<0.05$ ) inhibition of growth only at highest concentrations assayed ( Table 1 and Table 2). However, the growth of both species was affected at any terbutryn concentration tested, being the Chlorella vulgaris growth arrested ( Table 1 and Table 2).

Table 1.

Effect of atrazine and terbutryn on growth rate, dry biomass and viability of $S$. elongatus

Synechococcus elongatus

\begin{tabular}{|c|c|c|c|c|c|c|c|c|}
\hline \multirow{2}{*}{$\begin{array}{l}\text { Herbicide } \\
\text { concentrat } \\
\text { ion }(\mu \mathrm{M})\end{array}$} & \multicolumn{4}{|l|}{ Atrazine } & \multicolumn{4}{|l|}{ Terbutryn } \\
\hline & $\begin{array}{l}\text { Concentrati } \\
\text { on }\left(\mu g ~^{-1}\right)\end{array}$ & $\begin{array}{l}\text { Growth } \\
\text { rate }\left(d^{-1}\right)\end{array}$ & $\begin{array}{l}\text { Biomass( } \\
\left.\mu \mathrm{g} \mathrm{ml}^{-1}\right)\end{array}$ & $\begin{array}{l}\text { Viability } \\
(\%)\end{array}$ & $\begin{array}{l}\text { Concentr } \\
\text { ation }(\mu \mathrm{g} \\
\left.1^{-1}\right)\end{array}$ & $\begin{array}{l}\text { Growth } \\
\operatorname{rate}\left(d^{-1}\right)\end{array}$ & $\begin{array}{l}\text { Biomass } \\
(\mu \mathrm{g} \\
\left.\mathrm{ml}^{-1}\right)\end{array}$ & $\begin{array}{l}\text { Viability } \\
(\%)\end{array}$ \\
\hline Control & 0 & $3.23 \pm 0.13$ & $160 \pm 10$ & $\begin{array}{l}99 \pm 2.3 \\
3\end{array}$ & 0 & $3.17 \pm 0.08$ & $130 \pm 10$ & $\begin{array}{l}99 \pm 4.6 \\
5\end{array}$ \\
\hline 0.025 & 5.39 & $3.36 \pm 0.14$ & $\begin{array}{l}120 \pm 10 \\
*\end{array}$ & $\begin{array}{l}98 \pm 3.1 \\
5\end{array}$ & 6.03 & $1.26 \pm 0.11 *$ & $30 \pm 10^{*}$ & $\begin{array}{l}95 \pm 3.1 \\
7\end{array}$ \\
\hline 0.1 & 21.57 & $\begin{array}{l}2.68 \pm 0.12 \\
*\end{array}$ & $70 \pm 00^{*}$ & $\begin{array}{l}92 \pm 1.5 \\
1\end{array}$ & 24.40 & $0.78 \pm 0.03^{*}$ & $20 \pm 00^{*}$ & $\begin{array}{l}84 \pm 2.3 \\
4 *\end{array}$ \\
\hline 0.75 & 161.77 & $\begin{array}{l}1.11 \pm 0.07 \\
*\end{array}$ & $30 \pm 00 *$ & $\begin{array}{l}90 \pm 3.4 \\
8\end{array}$ & 181.02 & $\begin{array}{l}0.14 \pm 0.004 \\
*\end{array}$ & $20 \pm 00^{*}$ & $\begin{array}{l}80 \pm 3.1 \\
2^{*}\end{array}$ \\
\hline
\end{tabular}

Herbicides were added to the culture medium at the concentrations indicated. Values shown correspond to determinations performed $24 \mathrm{~h}$ after herbicide addition.

Table 2.

Effect of atrazine and terbutryn on growth rate, dry biomass and viability of $C$. vulgaris

Chlorella vulgaris

\begin{tabular}{|c|c|c|c|c|c|c|c|c|}
\hline \multirow{2}{*}{$\begin{array}{l}\text { Herbicide } \\
\text { concentrati } \\
\text { on }(\mu \mathrm{M})\end{array}$} & \multicolumn{4}{|l|}{ Atrazine } & \multicolumn{4}{|c|}{ Terbutryn } \\
\hline & $\begin{array}{l}\text { Concentrat } \\
\operatorname{ion}\left(\mu \mathrm{g}^{-1}\right)\end{array}$ & $\begin{array}{l}\text { Growth } \\
\text { rate }\left(d^{-1}\right)\end{array}$ & $\begin{array}{l}\operatorname{Biomass}(\mu \mathrm{g} \\
\left.\mathrm{ml}^{-1}\right)\end{array}$ & $\begin{array}{l}\text { Viability } \\
(\%)\end{array}$ & $\begin{array}{l}\text { Conce } \\
\text { ntrati } \\
\text { on }(\mu \mathrm{g} \\
\left.1^{-1}\right)\end{array}$ & $\begin{array}{l}\text { Growth } \\
\text { rate }\left(d^{-1}\right)\end{array}$ & $\begin{array}{l}\text { Biomas } \\
\mathrm{s}(\mu \mathrm{g} \\
\left.\mathrm{ml}^{-1}\right)\end{array}$ & Viability $(\%)$ \\
\hline Control & 0 & $0.38 \pm 0.01$ & $130 \pm 10$ & $\begin{array}{l}99 \pm 4.2 \\
2\end{array}$ & 0 & $\begin{array}{l}0.43 \pm 0.0 \\
2\end{array}$ & $\begin{array}{l}120 \pm 0 \\
0\end{array}$ & $99 \pm 4.32$ \\
\hline 0.025 & 5.39 & $0.45 \pm 0.03$ & $120 \pm 10^{*}$ & $\begin{array}{l}99 \pm 2.3 \\
1\end{array}$ & 6.03 & $\begin{array}{l}0.00 \pm 0.0 \\
2 *\end{array}$ & $\begin{array}{l}70 \pm 00 \\
*\end{array}$ & $99 \pm 2.56$ \\
\hline 0.1 & 21.57 & $0.39 \pm 0.02$ & $120 \pm 10 *$ & $\begin{array}{l}98 \pm 3.5 \\
4\end{array}$ & 24.40 & $\begin{array}{l}0.00 \pm 0.0 \\
0 *\end{array}$ & $\begin{array}{l}70 \pm 00 \\
*\end{array}$ & $95 \pm 2.35$ \\
\hline 0.75 & 161.77 & $\begin{array}{l}0.00 \pm 0.02 \\
*\end{array}$ & $110 \pm 10 *$ & $\begin{array}{l}95 \pm 3.8 \\
1\end{array}$ & $\begin{array}{l}181.0 \\
2\end{array}$ & $\begin{array}{l}0.00 \pm 0.0 \\
2 *\end{array}$ & $\begin{array}{l}60 \pm 10 \\
*\end{array}$ & $94 \pm 5.20$ \\
\hline
\end{tabular}

Herbicides were added to the culture medium at the concentrations indicated. Values shown correspond to determinations performed $24 \mathrm{~h}$ after herbicide addition.

\subsection{Dry biomass}

In $S$. elongatus cultures, dry biomass (expressed as $\left.\mu \mathrm{g} \mathrm{ml}^{-1}\right)$ decreased significantly $(P<0.05)$ by the addition of herbicides at all concentrations assayed ( Table 1). This effect was more important for terbutryn, since the lowest concentration assayed $(0.025 \mu \mathrm{M})$ reduced four times the dry weight observed in control cultures ( Table 1). 
In C. vulgaris the decrease in biomass of cultures containing either herbicide was also significant for all concentrations assayed ( Table 2). In these microalgal cultures, terbutryn reduced twice the dry biomass of control cultures in all concentrations assayed ( Table 2).

\subsection{Cell viability}

Cell viability in $S$. elongatus cultures was affected by the addition of terbutryn( Table 1). In cultures with atrazine concentrations of 0.1 and $0.75 \mu \mathrm{M}$, viability was reduced to $92 \%$ and $90 \%$, respectively, not differing significantly $(P<0.05)$ from the viability of control cultures $(99 \%)$. Viability percentage in cultures with concentrations of 0.1 and $0.75 \mu \mathrm{M}$ terbutryn decreased significantly to $84 \%$ and $80 \%$, respectively ( Table 1 ).

In C. vulgaris there were no significant differences in viability between control cultures $(99 \%)$ and cultures with either herbicide, even at the highest concentrations of atrazine $(95 \%)$ and terbutryn (94\%) ( Table 2).

\subsection{Uptake of herbicides from the culture medium and bioaccumulation in the biomass}

\subsubsection{Synechococcus elongatus}

The percentage of atrazine taken up increased slightly from $10 \mathrm{~min}$ to $6 \mathrm{~h}$ of exposure, for all concentrations assayed. The maximum difference in the uptake rate was observed between 6 and $12 \mathrm{~h}$ (Fig. 1). The percentage of atrazine uptake did not change after twelve hours of culture; in cultures of $0.025 \mu \mathrm{M}$ uptake was near $80 \%$ of the total amount of pesticide in the culture at $12 \mathrm{~h}$, and close to $70 \%$ in $0.75 \mu \mathrm{M}$ cultures (Fig. 1A).
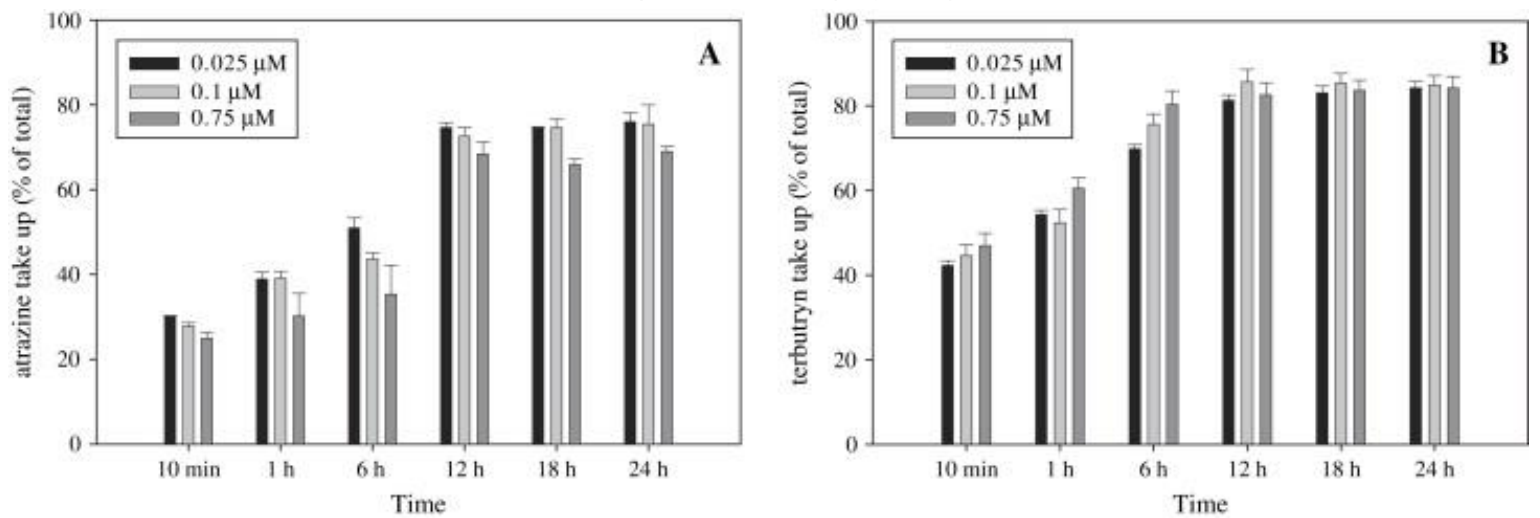

Fig. 1 .

Uptake of atrazine and terbutryn by $S$. elongatus. At time zero, the culture medium was supplemented with atrazine $(A)$ or terbutryn $(B)$ at the final concentrations indicated.

In the case of terbutryn the evolution of the uptake was similar to the described above for atrazine, but at the initial time $(10 \mathrm{~min})$ the uptake was near $50 \%$ including to the highest concentration assayed (Fig. 1B). No differences were observed after $12 \mathrm{~h}$ of exposure, removing more than $80 \%$ of added terbutryn (Fig. 1B). 
Data on herbicide bioaccumulation in microalgal biomass revealed that the limit value of accumulated herbicide is $9 \mu \mathrm{mol}$ atrazine $\mathrm{g}^{-1}$ dry biomass(Fig. 2A), obtained after $12 \mathrm{~h}$ of culture, and $12 \mu \mathrm{mol}$ terbutryn $\mathrm{g}^{-1}$ dry biomass (Fig. 2B), at $18 \mathrm{~h}$ of culture.
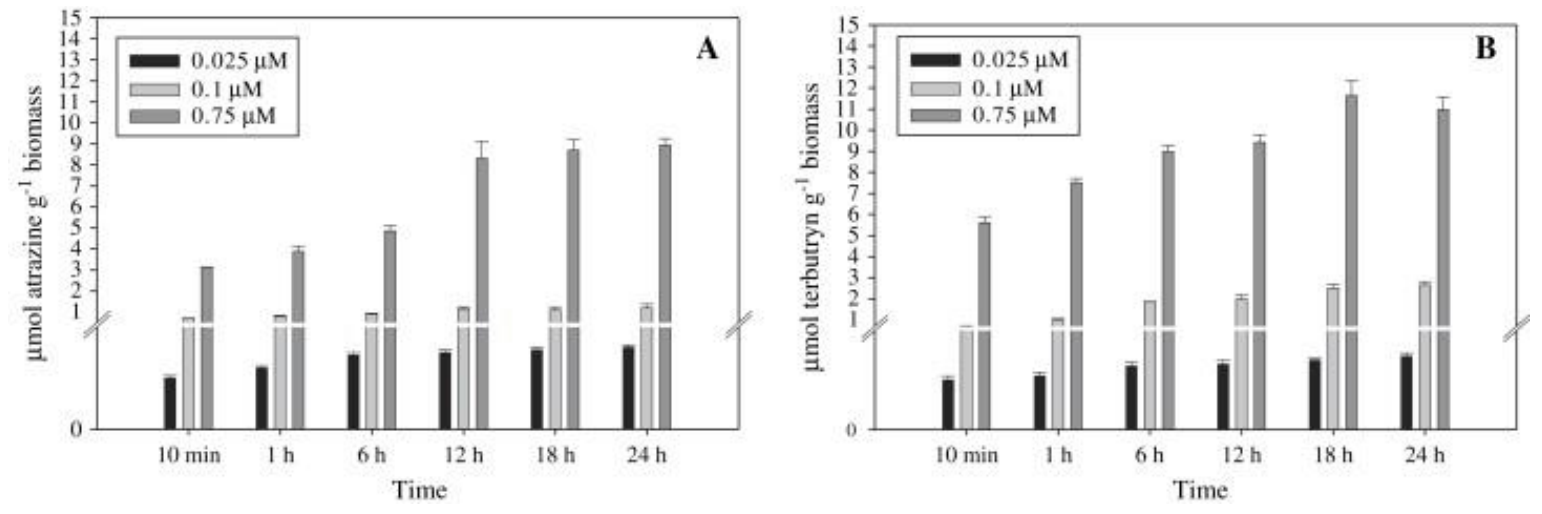

Fig. 2.

Bioaccumulation of triazine herbicides in $S$. elongatus biomass. At time zero, the culture medium was supplemented with atrazine $(A)$ or terbutryn (B) at the final concentrations indicated.

\subsubsection{Chlorella vulgaris}

The maximum percentage of uptake was after $12 \mathrm{~h}$ for either herbicide cultures. Atrazine uptake, at this time, was between $83 \%(0.75 \mu \mathrm{M})$ and $90 \%(0.1 \mu \mathrm{M})($ Fig. $2 \mathrm{~A})$. Terbutryn uptake was between $85 \%(0.025 \mu \mathrm{M})$ and $93 \%(0.75 \mu \mathrm{M})$. After $12 \mathrm{~h}$, the concentrations of both herbicides in all cultures did not vary (Fig. 2B).

Bioaccumulation of herbicides in microalgal biomass had a limit value of $11 \mu \mathrm{mol}$ atrazine $\mathrm{g}^{-}$ 1 dry biomass (Fig. 4A); this quantity was obtained at six hours of culture, and decreased significantly after $12 \mathrm{~h}$. In the case of terbutryn $12 \mu \mathrm{mol} \mathrm{g}{ }^{-1}$ dry biomass was the limit value of bioaccumulation in C. vulgaris biomass, obtained at $18 \mathrm{~h}$ of culture ( Fig. 4B).

\section{Discussion}

Triazine herbicides provoke serious damage in natural microalgal populations (Dorigo et al., 2004). Some authors suggest that the bioconcentration of atrazine might be a prerequisite for toxicity in microalgal cells (Tang et al., 1998). In this study some effects provoked by the herbicides are shown. Table 1 and Table 2both show the serious effects on growth for microalgae by herbicide addition to culture medium. The effects on growth of terbutryn seem to be more acute than those of atrazine for either species. C. vulgaris cultures growth ceased completely in presence of all terbutryn concentrations assayed ( Table 2), suggesting that green microalga are more sensitive to its effects than $S$. elongatus, since the growth of cyanobacterial cultures decreased significantly, but did not cease ( Table 1).

But there are other important parameters besides growth in the removal of herbicides from culture medium, as it could be the viability of cells, and the stability of the microalgal biomass after herbicide uptake. The main characteristic of cell death or decrease of cell viability, whether from senescence, acute stress, or aging, seems to be the loss of the ability of cells to maintain 
homeostasis (Gahan, 1984). Cellular membranes are selective, dynamic barriers that play an essential role in regulating biochemical and physiological events. The decrease in cell viability, assayed by flow cytometry, is related to the loss of membrane integrity, similar to that which occurs in the aging and senescence process (Thompson, 1988 and Cid et al., 1996). Addition of concentrations of terbutryn higher than $0.1 \mu \mathrm{M}$ significantly reduces cell viability in $S$. elongatus cultures. This reduction of the cell viability was not observed for any of the remaining cultures of either species ( Table 1 and Table 2).

The biomass of the two microalgal species is also affected by the addition of either herbicides (Table 1 and Table 2), mainly by terbutryn which reduced nearly $10 \%$ of the biomass of $C$. vulgaris cultures exposed to the highest concentration assayed. Cultures exposed to the concentrations that affected microalgal growth showed cells larger than normal cells, due to the impossibility of completing their cell division. This effect was reported previously in $S$. elongatus cultured with atrazine ( González-Barreiro et al., 2004).

The combined effect over growth, stability of microalgal biomass and cell viability must be taken into account when the triazine herbicide bioconcentration capability is studied for the potential application of these microorganisms to environmental problems. Other studies performed with chlorophytes and bacillariophytes revealed that other factors such as cell size and density could provoke differences in atrazine bioconcentration (Weiner et al., 2004).

In C. vulgaris cultures exposed to the highest concentration assayed, more than $75 \%$ of atrazine was removed from the culture medium after $12 \mathrm{~h}$ of exposure ( Fig. 3), but posterior analysis showed that herbicide concentration per gram of dry biomass decreased ( Fig. 4), while differences in the viability of the microalgal population with respect to the control were not observed. These results indicate that the atrazine bioacumulation expressed as a function of dry biomass could lead to an incorrect interpretation of data, since this value could indicate a release of the herbicide from cells ( Fig. 4), that does not occur taking into account the other results ( Fig. 3).
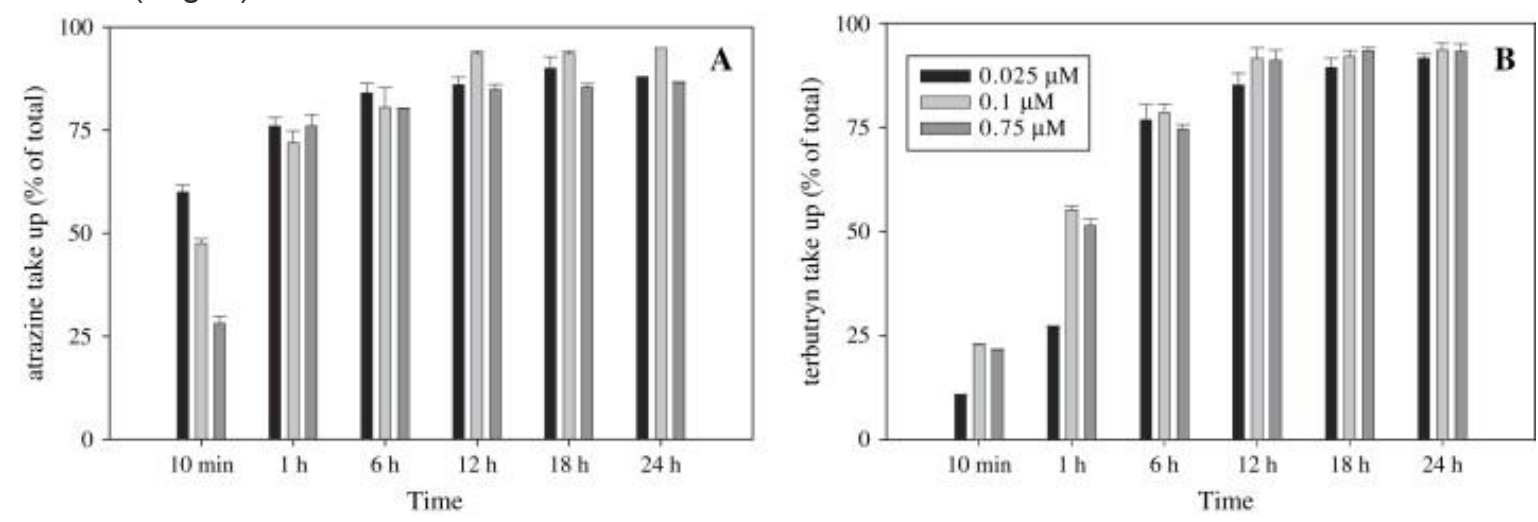

Fig. 3.

Uptake of atrazine and terbutryn by $C$. vulgaris. At time zero, the culture medium was supplemented with atrazine $(A)$ or terbutryn $(B)$ at the final concentrations indicated. 

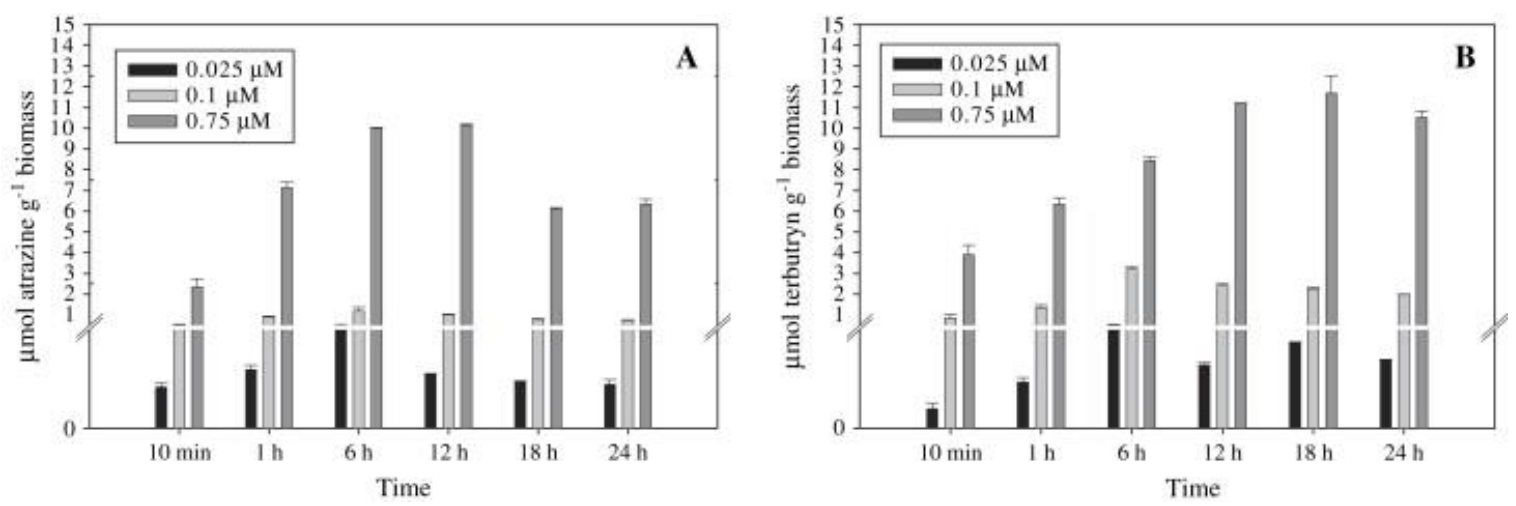

Fig. 4.

Bioaccumulation of triazine herbicides in C. vulgaris biomass. At time zero, the culture medium was supplemented with atrazine $(A)$ or terbutryn $(B)$ at the final concentrations indicated.

As indicated previously both herbicides affect the growth of $C$. vulgaris but not cell viability ( Table 2). This fact can be translated into a quick bioaccumulation of herbicides in the microalgal biomass. However, in the cyanobacterium cultures exposed to terbutryn, the viability of population decreased significantly, but pesticides are retained in the microalgal biomass, and do not appear in the medium again ( Fig. 1 and Fig. 2), even in those cells that are not viable, the pesticide is not liberated. Based on this, it seems that $C$. vulgariscells are capable of maintaining their cellular integrity whereas $S$. elongatus are not. This fact could be relevant in the effectiveness of uptake of pesticides.

Differences in bioconcentration are also due to the morphological and physiological characteristics of the cells, such as the lipid content of cell membranes and composition of cell walls(Tang et al., 1998). Chlorella vulgaris is an eukaryotic microalga whereas S. elongatus is a prokaryotic cyanobacteria and their cell walls and membranes are quite different in their lipid composition. Other works reveal the difference in the speed of entrance of different herbicides, such as isoproturon and terbutryn, into $C$. vulgaris as a function of their polarity and their capacity of dilution into the lipids of cell membranes ( Rioboo et al., 2002). As shown in this work, speed of entrance of herbicides depends on either the microalgae species and the herbicide assayed (Fig. 1 and Fig. 3). Some authors affirm that the first step in the uptake of herbicides in the sorption of organic compounds is mainly a passive process involving a chemical partitioning into the hydrophobic biomass (Amy et al., 1998). Based on the partitioning coefficient of atrazine $\left(\log K_{\text {ow }} 2.56\right)$ and terbutryn $\left(\log K_{\text {ow }} 3.49\right)$, this herbicide is more lipophilic than atrazine. This can explain the results obtained in which terbutryn is rapidly taken up, as a passive uptake, from the medium by the cells.

\section{Conclusions}

The results included in this work establish the potential of the microalga $C$. vulgaris and the cyanobacteriumS. elongatus, for their use in the treatment of waters polluted with triazine herbicides. Actually, $C$. vulgarisseems to be slightly superior to $S$. elongatus, since this microalga exhibits higher cell viability. Moreover, both photosynthetic organisms are amenable 
to mass culture production, which would facilitate the establishment of bioremediation systems based on these microorganisms.

\section{Acknowledgements}

This work was carried out with the financial support of the Consellería de Innovación, Industria e Comercio, Xunta de Galicia (PGIDIT04RFO103946PR). C.R. acknowledges a F.P.U. fellowship from the Spanish Ministerio de Educación y Ciencia. Many thanks also to the anonymous referees of this paper who have contributed to its improvement.

\section{References}

G.L. Amy, C.W. Bryant, B.C. Alleman, W.A. Barkley

Biosorption of organic halide in a Kraft mill generated lagoon

J. Water Pollut. Control Fed., 60 (1998), pp. 1445-1457

H. Blank, G. Wallin, S. Wanberg

Species-dependent variation in algal sensitivity to chemical compounds

Ecotoxicol. Environ. Saf., 8 (1984), pp. 339-351

T.E. Brown, F.L. Richardson, M.L. Vaughn

Development of red pigmentation in Chlorococcum wimmeri (Chlorophyta: Chlorococcales)

Phycologia, 6 (1967), pp. 167-184

A. Cid, P. Fidalgo, C. Herrero, J. Abalde

Toxic action of copper on the membrane system of a marine diatom measured by flow cytometry

Cytometry, 25 (1996), pp. 32-36

U. Dorigo, X. Bourrain, A. Bérard, C. Leboulanger

Seasonal changes in the sensitivity of river microalgae to atrazine and isoproturon along a contamination gradient

Sci. Total Environ., 318 (2004), pp. 101-114

P.B. Gahan

Reversible and irreversible damage in plant cells of different ages

I. Davies, D.C. Sigee (Eds.), Cell Ageing and Cell Death, Cambridge University Press, London, UK (1984), pp. 155-169

O. González-Barreiro, C. Rioboo, A. Cid, C. Herrero

Atrazine-induced chlorosis in Synechococcus elongatus cells 
Arch. Environ. Contam. Toxicol., 46 (2004), pp. 301-307

M. Graymore, F. Stagnitti, G. Allinson

Impacts of atrazine in aquatic ecosystems

Environ. Int., 26 (2001), pp. 483-495

R.A. Kent, D. Currie

Predicting algal sensitivity to a pesticide stress

Environ. Toxicol. Chem., 14 (1995), pp. 983-991

J. Ma, J. Chen

How to accurately assay the algal toxicity of pesticides with low water solubility

Environ. Pollut., 136 (2005), pp. 267-273

M. Manthey, M. Faust, S. Smolka, L.H. Grimme

Herbicide bioconcentration in algae: studies in lipophilicity-sorption-activity relationships (LSAR) with Chlorella fusca

Sci. Total Environ., 1 (1993), pp. 453-459

P.V. McCormik, J.J. Cairns

Algae as indicators of environmental change

J. Appl. Phycol., 6 (1994), pp. 509-526

C. Rioboo, O. González, C. Herrero, A. Cid

Physiological response of freshwater microalga (Chlorella vulgaris) to triazine and phenylurea herbicides

Aquat. Toxicol., 59 (2002), pp. 225-235

R.A. Rebich, R.H. Coupe, E.M. Thurman

Herbicide concentrations in the Mississippi River Basin - the importance of chloroacetanilide herbicide degradates

Sci. Total Environ., 321 (2004), pp. 189-199

S. Singh, R.C. Kirwood, G. Marshall

Effects of isoproturon on photosynthesis in susceptible and resistant biotypes of Phalaris minor and wheat

Weed Res., 37 (1997), pp. 315-324

K.R. Solomon

Ecological risk assessment of atrazine in North America surface waters 
Environ. Toxicol. Chem., 15 (1996), pp. 31-76

J. Tang, K.D. Hoagland, B.D. Siegfried

Uptake and bioconcentration of atrazine by selected freshwater algae

Environ. Toxicol. Chem., 17 (1998), pp. 1085-1090

\section{J.E. Thompson}

The molecular basis for membrane deterioration during senescence

L.D. Noodén, A.C. Leopold (Eds.), Senescence and Aging in Plants, Academic Press, Inc, San Diego, California (1988), pp. 51-83

C. Tomlin

The Pesticide Manual. A World Compendium

(13th ed.)BCPC (British Crop Protection Council), Hampshire, UK (2003)

S.D. Utting

Influence of nitrogen availability on the biochemical composition of three unicellular marine algae of commercial importance

Aquac. Eng., 4 (1985), pp. 175-190

C. Védrine, J.-C. Leclerc, C. Durrieu, C. Tran-Minh

Optical whole-cell biosensor using Chlorella vulgaris designed for monitoring herbicides

Biosens. Bioelectron., 18 (2003), pp. 457-463

J.A. Weiner, M.E. DeLorenzo, M.H. Fulton

Relationship between uptake capacity and differential toxicity of the herbicide atrazine in selected microalgal species

Aquat. Toxicol., 68 (2004), pp. 121-128

Corresponding author. Tel.: +34 981167 000; fax: +34 981167065 .

Copyright () 2006 Elsevier Ltd. All rights reserved 